\title{
ANALYSING NATIONAL SECESSIONIST MOVEMENTS: FROM A TACTICAL VIEWPOINT TOWARDS STRATEGIC UNDERSTANDING?
}

DOI: $10.20542 / 2307-1494-2021-1-204-206$

\author{
Roeder, Philip G. National Secession: \\ Persuasion and Violence in Independence \\ Campaigns. - Ithaca (N.Y.): Cornell \\ University Press, 2018. 198 p.
}

In "National Secession", Philip Roeder presents a new analytical framework for understanding the development of national-secession projects. In his book he lays out how "programmatic analysis" can explain the means by which secessionist movements are able to rise to prominence, bring about political stalemates, and operate in the long term. The key to these questions of development, engagement and political longevity is presented by Roeder as the ideas of programmatic coordination and pre-emption, rather than motivations of individuals as advocated by other scholars. Roeder makes the case that everything, from the unleashing of "political surges" to the use of violence and even the day-to-day recruitment drives of national secessionist movements depend on the management of the connection of their social base (the population) to "the program", i. e. to the singularly-defined goal of territorial and political sovereignty.

By analysing a wide range of nationalist secessionist movements from 1946 to 2016, Roeder constructs a data set to analyse the various factors that are a part of these political projects including: rates of political exclusion, platform population size, and experience of prior statehood (p. 103). Combining these datasets and the subsequent statistical analysis with a range of political theories of mobilisation (referencing the works of Vladimir Lenin and Miroslav Hroch, among many others), Roeder provides a multifaceted analysis of the difficulties and considerations needed to expand these movements, from a top-down perspective. Roeder analyses the way in which leaders of secessionist movements need to be able to provide their platform population with a consistently marked homeland, the way in which the perception of this homeland is vital for the perceived viability of the secessionist program, and its statistical boost to those secessionist movements that have had it in the past. Such a defined homeland, Roeder argues, is absolutely necessary as a unifying point for the nation that as yet remains imaginary, in order to prevent ideological drift and keep members of the platform population from losing sight of the major programmatic goal, i. e. programmatic coordination (p. 106). It is worth clarifying Roeder's use of the term "program" that he understands as "an analysis explaining why the solution to the problems that give rise to energizing emotions is independence" and "a plan of action" (p. 175). The above concept of the homeland and of how it relates to the program ties together the ideological aspects of political leadership, the narrative at the heart of nationalist political struggle, and the evidence of the results of the strategy itself.

A key part of Roeder's programmatic analysis is unpacking how the program interacts with participants. To that end Roeder introduces a lot of key concepts, most notably the classification of political actors in national secessionist movements. Noting that no person is purely one type, he sorts members of these political forces into three main types: "expressionists" who see the struggle as the reason for participation, "enthusiasts" who aim to complete the goal of the program, and "pragmatists" who see independence as their opportunity to advance their position (pp. 16, 71-72). Roeder highlights how these participants not only carry their own set of motivations for joining the secession, but are also suited for certain activities above others: for instance, pragmatists are better suited for maintaining a cohesive and functional party structure, 
while expressionists are best for mobilising the followers into mass action. All of these characteristics, Roeder argues, have specific roles in the promotion of the program and need to be understood by the secessionist leaders, to further capture the platform population. The phrasing and construction of this triad of motivations appears to make sense when placed in the context of the political strategies of secessionist campaigns, but to a reader it doesn't seem entirely clear on what evidence this construction is based.

The analytical level and scope of the book are impressive, but with such a wideranging and spiralling discussion of political interactions, the risk could arise that major points will get lost within the text. However, Roeder's decision to mark out the central political hypotheses in boxes saves the reader from the undue stress of circling back and re-examining the text and accompanying data for its main takeaway, and understanding the "costly collaboration" hypothesis, for example, is rendered much easier (p. 168).

Roeder's analysis of statistical trends is broken down into ten hypotheses throughout the book that are clearly marked out. Each hypothesis provides a part of the answer to the foundational question of the text: "What makes some national secession projects grow to become significant"? For instance, the "proposed state viability" hypothesis argues that "an ethnic group is more likely to become the platform of a significant national-secession campaign against a common-state if the platform population is comparable in size to the population of existing sovereign states" (p. 110). One thing that would be useful for a reader of "National Secessions" is the conclusive reintegration of these hypotheses into some kind of visual aid that demonstrates how they interact with the theory of "programmatic coordination".

Roeder's analysis is not limited to theoretical, statistical and big picture examinations of secessionist movements as a phenomenon. The book also features case studies of several movements such as that of Donbas (Novorossiya), Eritrea and East Timor and shows how achieving or losing programmatic coordination decided their political fates. In these case studies, Roeder compares and contrasts the efforts of the academics, leaders, and supporters of these movements, and in doing so, provides an excellent test run of his programmatic theory. For instance, his study of the role of violence in the East Timor secessionist movement reveal a subtle and yet surprisingly practical driver for resort to terrorism (which might otherwise seem random or sporadic) that of reinvigorating programmatic coordination, following a crackdown by the Indonesian government that had left secessionist actors isolated and unsure of other's motivations (p. 156).

Interestingly, Roeder's concluding thoughts on the use of programmatic theory focus not so much on the secessionists as on the strategy required of mother-state (common-state) governments to supress such movements. Roeder's solution is essentially an endorsement of his programmatic theory in that he calls for the creation of a rival, government-led visionary conception of the country that is tied to the parochial needs of the population and can pull support away from the competing vision of the proposed new state of the secessionists. Roeder also notes the precarious nature of foreign backing that can hinder as well as help increase the legitimacy of the commonstate's program and points at the risk of tying the government to "illegitimate interventionist powers" (p. 198).

Overall, the book seeks to bring into the academic debates on nationalist secessions more discussion of the practical goals, rhetorical objectives and theoretical approaches of mass mobilisation in the name of a secessionist political cause. It may seem that Roeder's aim is to criticise or supplant former motivations-based literature on the roots of secessionist conflict (such as the P.Collier - A.Hoeffler's greed vs grievance debate). ${ }^{1}$ However, according to Roeder, "programmatic theory does not dismiss the findings of these earlier theories; it sees them as highlighting complements to the core task of programmatic coordination" (p. 172). Roeder uses his programmatic theory to 
build up a compelling argument for broad-scale strategic understanding of secessionist politics. He identifies the various steps that secessionist movements and their leaders take, such as making people sympathetic, sustaining interest, and achieving intractable positions with the common state government and international recognition. All of these facets are bounded within the well-defined and tightly-constructed rigours of the "the program", resulting in a simultaneous education in the process of secessionist growth and management, and political decision strategy making and its practical effects.

In general, the book is an interesting and novel approach to understanding why there are so many ethnic groups with vague ideas of self-determination, yet so much fewer sustained, effective secessionist movements. The focus on practical actions of secessionist actors and the explanations on the reasoning for such actions are particularly useful. For example, Roeder's analysis provides a logical and intelligent explanation of the engagement of small secessionist groups in apparently hopeless conflicts with large common-state governments. He reveals how such actions can act in multiple ways to actually serve the nationalist program: for instance, by demonstrating "state-like" powers, showing off extreme motivation to the rest of the population, and drawing the attention of the international community. Where rationale seemed missing, it starts to appear as the analysis moves from the tactical to the strategic level.

Overall, the "programmatic coordination" theory and other concepts developed in the book resonate well with previous scholarship that seeks to understand motivations. If the motivational viewpoint reflects the tactical understanding of the situation from the civilian perspective and the programmatic viewpoint reflects a political strategist's analysis, then the synthesis of these two approaches can only yield greater analytical and predictive results in the form of a more complete picture of what is undoubtedly a pressing cause for concern in world affairs. One might think of these frameworks as the two lenses within a telescope, each with a different function (gathering vs focusing), that need to be superposed to provide the clearer image.

The book is an excellent complement to other works on the rise of secessionist conflict, and perhaps second to none among analyses of strategies of nationalistseparatist political mobilisation. While the final chapter is a bit too concise, the book is well-structured and makes use of technical decisions to highlight hypotheses based on statistical analysis. Additionally, the sometimes dispassionate way in which the author tackles political machinations, such as the way leaders need to be able to switch identity in relation to their audience to tie their issues to the program, provides a refreshing realist look at the nuts and bolts of political mobilisation along ethnic and national lines. Furthermore, given the way the book is attempting to push scholarship into a somewhat new direction, the author's appreciation for the merits of previous analytical lenses is also refreshing. The book is recommended to anyone interested in how vague ethnic tensions can transform into mass-based political and social movements and why they may choose to engage in violence.

Frederik Boumeester (The Netherlands) European University in Saint Petersburg

ORCID: 0000-0003-4096-6443

(c) F.Boumeester, 2021

\section{ENDNOTES}

\footnotetext{
${ }^{1}$ Collier P., Hoeffler A. Greed and grievance in civil war // Oxford Economic Papers. V. 56. 2004. P. 563-595. DOI: 10.1093/oep/gpf064.
} 